\title{
Antibacterial Effect of Jatropha multifida L. Leaf Infusion towards Staphylococcus aureus and Pseudomonas aeruginosa
}

\author{
Ivan, ${ }^{1}$ Sunarjati Sudigdoadi, ${ }^{2}$ Achmad Hussein S. Kartamihardja ${ }^{3}$ \\ ${ }^{1}$ Faculty of Medicine Universitas Padjadjaran, ${ }^{2}$ Department of Biomedical Sciences Faculty of \\ Medicine Universitas Padjadjaran, ${ }^{3}$ Department of Nuclear Medicine and Molecular Imaging, \\ Faculty of Medicine Universitas Padjadjaran/Dr. Hasan Sadikin General Hospital, \\ Bandung, Indonesia
}

\begin{abstract}
Background: Jatropha multifida is one of the medicinal plants commonly found in Indonesia. This plant is used in the community to heal open wounds, however, scientific evidence is lacking. The two most common bacteria which often cause infection in open wounds are Staphylococcus aureus and Pseudomonas aeruginosa. This study aimed to determine the antibacterial effect of $J$. multifida leaf infusion towards $S$. aureus and P. Aeruginosa in vitro.

Methods: This was an experimental laboratory study conducted at the Microbiology Laboratory, Faculty of Medicine, Universitas Padjadjaran in 2014. The modified Kirby-Bauer antimicrobial diffusion procedure on Mueller-Hinton agar was applied to determine the inhibitory zone. In determining the minimum inhibitory concentration (MIC) and the minimum bactericidal concentration (MBC), the modified technique of tube dilution was used.

Results: The results of this research showed that the infusion of $J$. multifida leaves had inhibitory effects on the growth of $S$. aureus dan P. aeruginosa at the concentration of $100 \%$ and $75 \%$. The minimum inhibition concentration and minimum bactericidal concentration could not be determined. Conclusions: There is evidence confirming the bacteriostatic antibacterial effect of $J$. multifida leaves which inhibits the growth of $S$. aureus and P. Aeruginosa. Further study is needed to explore J. multifida leaves.
\end{abstract}

Keywords: Antibacterial effect, infusion, Jatropha multifida leaf, P. aeruginosa, S. aureus

\section{Introduction}

Indonesia is a country rich in natural resources and biological diversity, one of which is found in medicinal plants. Since historical times, Indonesians have been using various types of traditional medicinal plants to cure various ailments, one of which is coral plants or Jatropha multifida Linn (J. multifida). ${ }^{1}$ Benefits of J. multifida have not been well known to common Indonesian. The parts of this plant that can be used are its leaves, sap, and seeds oil, which have been utilized to treat helminthiasis, infections in open wounds, and various inflammatory conditions of the skin. ${ }^{2}$

Generally, an extract of the parts of a particular plant is used to test the plant's potential effects and therapeutic benefits. One of the more readily made extracts is a liquid extract, which is produced by using solvents as extractors. Solvents that are commonly used are water and ethanol 95\%. The most frequently used methods to create liquid extracts are by dedoctum and infusum, which utilize water as the solvent. ${ }^{3}$ In this study, the infusum method was used because it is cheaper, faster, and simpler, which makes it more available to common people.

Open wounds happen when the skin or the mucosal surface experiences destruction. This destruction causes increased exposure to infectious agents, one of which is bacteria. One of the bacteria that commonly infect open wounds is Staphylococcus aureus. ${ }^{4}$ Beside $S$. aureus, Pseudomonas aeruginosa is another bacteria that commonly cause open wound infection and also nosocomial infection. ${ }^{5}$

Based on these facts, the author is interested to study the antibacterial effect of J. multifida leaves, in the form of an infusion, against $S$. aureus, which represents Gram-

Correspondence: Ivan, Faculty of Medicine, Universitas Padjadjaran, Jalan Raya Bandung-Sumedang Km.21, Jatinangor, Sumedang, Indonesia, Email: ucokzzmail@gmail.com 
positive bacteria, and $P$. aeruginosa, which represents Gram negative bacteria, as bacteria that commonly cause open wound infection.

\section{Methods}

This was an experimental laboratory study, approved by the Research Ethics Committee Universitas Padjadjaran. The study was carried out in the Microbiological Laboratory Faculty of Medicine Universitas Padjadjaran in Jatinangor in October 2014.

The study comprised of four stages: (i) making of $J$.multifida leaf infusion, (ii) making of bacterial suspension, (iii) determination of antibacterial effect with antimicrobial infusion method of Kirby Bauer that had been modified on Mueller Hinton agar, and (iv) determination of minimum inhibitory concentration (MIC) and minimum bactericidal concentration (MBC) with modified tube dilution method.

On the first stage, J. multifida leaf infusion was made. J. multifida leaves were washed, and then dried and finely cut. $100 \%$ concentration was achieved by putting $20 \mathrm{~g}$ of leaves into 20 $\mathrm{g}$ of water. It was heated at $90^{\circ} \mathrm{C}$ for 15 minutes and stirred every 5 minutes. After cooling it down, the mixture was filtered using sterile gauze until no more water was left. The $100 \%$ infusion was diluted to make $75 \%, 50 \%$, and $25 \%$ infusions.

On the second stage, bacterial suspension was made. The bacterial colony was grown on Mueller Hinton agar in a petri dish and incubated for 24 hoursat $37^{\circ} \mathrm{C}$. Afterincubation, bacteria were taken using an inoculating loop for 4-5 times and then inserted into a reaction tube filled with distilled water to produce a suspension until the turbidity achieved McFarland standard 0.5. ${ }^{6}$ This suspension was equivalent to $1.5 \times 108 \mathrm{CFU} / \mathrm{mL}$.

In the third stage, the antibacterial effect was determined. A milliliter of bacterial suspension was added into a petri dish, then the dish was filled with $24 \mathrm{~mL}$ Mueller Hinton agar at 40$50^{\circ} \mathrm{C}$. It was then homogenized and let to cool down until it solidified with $\pm 4 \mathrm{~mm}$ thickness. Five holes with $10 \mathrm{~mm}$ diameter and $4 \mathrm{~mm}$ depth were made on the solidified agar. Four holes were filled with $0.3 \mathrm{~mL}$ of $J$. multifida leaf infusion with different concentrations: $100 \%$, $75 \%, 50 \%$, and $25 \%$. The fifth hole was filled with distilled water as a positive control. The dish was then incubated for 24 hours at $37^{\circ} \mathrm{C}$ in the incubator. After 24 hours, the diameter of bacterial growth inhibition zones at each hole was measured. These zones appeared as clear areas surrounding each hole.

On the fourth stage, MIC and MBC were determined. To determine MIC, ten reaction tubes and J. multifida infusions with different concentrations: $100 \%, 50 \%, 25 \%, 12.5 \%$, $6.25 \%, 3.13 \%, 1.56 \%$, and $0.78 \%$. The first to the eight tubes were filled $1 \mathrm{~mL}$ of infusion, each one with a different concentration.

A milliliter liquid Mueller Hinton agar that had been added with bacterial suspension $(0.5$ McFarland turbidity) was added to the eight tubes that contained infusion, and then the tubes were shaken for homogenization. The end concentrations would be the following: $50 \%, 25 \%, 12.5 \%, 6.25 \%, 3.13 \%, 1.56 \%$, $0.78 \%$, and $0.39 \%$. The ninth reaction tube was filled with the same liquid Mueller Hinton agar (with bacterial suspension) as positive control and the tenth tube was filled

Table 1 Diameter of Inhibitory Zones of $S$. aureus and P. aeruginosa with Different Concentrations of $J$. multifida Leaf Infusion

\begin{tabular}{|c|c|c|c|c|c|}
\hline \multirow{2}{*}{ Bacteria } & \multirow{2}{*}{$\begin{array}{c}\text { Concentration } \\
(\%)\end{array}$} & \multicolumn{3}{|c|}{ Diameter of inhibitory zone (mm) } & \multirow{2}{*}{$\begin{array}{c}\text { Average } \\
\text { (mm) }\end{array}$} \\
\hline & & I & II & III & \\
\hline \multirow{4}{*}{ S. aureus } & 100 & 25 & 22 & 17 & 21.3 \\
\hline & 75 & 20 & 19 & 13 & 17.3 \\
\hline & 50 & - & - & - & - \\
\hline & 25 & - & - & - & - \\
\hline \multirow{4}{*}{ P. aeruginosa } & 100 & 20 & 18 & 18 & 18.7 \\
\hline & 75 & 14 & 15 & 14 & 14.3 \\
\hline & 50 & - & - & - & - \\
\hline & 25 & - & - & - & - \\
\hline
\end{tabular}


with liquid Mueller Hinton agar and 100\% J. multifida infusion as a negative control.

Next, all ten reaction tubes were put into the incubator for 24 hours at $37^{\circ} \mathrm{C}$. After incubation, the turbidity of each tube was observed to examine the MIC. Tubes that were clearer than the negative control indicated the presence of an antibacterial effect.

To determine MBC, as much as 1 inoculating loop of the mixture from each tube was taken and smeared on Mueller Hinton agar. It was next incubated for 24 hours at $37^{\circ} \mathrm{C}$ for observation. The above procedure was repeated for 3 times with new infusion but identical treatment.

\section{Results}

Determination of the antibacterial effect of $J$. multifida leaf infusion against $S$. aureus and $P$. aeruginosa was done by measuring the diameter of the inhibitory zones.

Table 1 shows that at $100 \%$ and $75 \%$ concentrations, J. multifida leaf infusion has an antibacterial effect against $S$. aureus and $P$. aeruginosa. The antibacterial effect was bacteriostatic because there was still bacterial growth in the inhibitory zones. The growths were observed through Gram staining.

After MIC test observation for 24 hours with the tube dilution method, it was concluded that MIC of J. multifida leaf infusion against $S$. aureus and $P$. aeruginosa could not be determined because there were still visual observations of turbidity in every tube, indicating bacterial growth (Table 2).

From MBC test observation for 24 hours, using the culture from the previous MIC test, it was concluded that the MBC of J. multifida leaf infusion against $S$. aureus and $P$. aeruginosa could not be determined because there was still bacterial colony growth in $\mathrm{MH}$ agar regardless of the concentration of the infusion added (Table 3).

\section{Discussions}

This study has shown that inhibitory zones

Table 2 Bacterial Growth after MIC Test Against S. aureus and P. aeruginosa by J. multifida Leaf Infusion at Different Concentrations

\begin{tabular}{lccccccccccc}
\hline \multirow{2}{*}{ Bacteria } & \multicolumn{1}{c}{ Concentration (\%) } & \multicolumn{4}{c}{ Control } \\
\cline { 2 - 10 } & $\mathbf{5 0}$ & $\mathbf{2 5}$ & $\mathbf{1 2 . 5}$ & $\mathbf{6 . 2 5}$ & $\mathbf{3 . 1 3}$ & $\mathbf{1 . 5 6}$ & $\mathbf{0 . 7 8}$ & $\mathbf{0 . 3 9}$ & $\mathbf{C}(-)$ & $\mathbf{C}(+)$ \\
\hline \multirow{3}{*}{ S. aureus } & + & + & + & + & + & + & + & + & - & + \\
& + & + & + & + & + & + & + & + & - & + \\
\multirow{2}{*}{ P. aeruginosa } & + & + & + & + & + & + & + & + & - & + \\
& + & + & + & + & + & + & + & + & - & + \\
& + & + & + & + & + & + & + & + & - & + \\
\hline
\end{tabular}

Note: + : Bacterial colonies were present, - : Bacterial colonies were absent, $(+)$ : MH broth with tested bacteria suspension, (-) : 100\% J. multifida leaf infusion with MH broth

Table 3 Bacterial Growth in MBC Test against S. aureus and P. aeruginosa by J. multifida Leaf Infusion at Different Concentrations.

\begin{tabular}{lcccccccccc}
\hline \multirow{2}{*}{ Bacteria } & \multicolumn{1}{c}{ Concentration (\%) } & \multicolumn{3}{c}{ Control } \\
\cline { 2 - 10 } & $\mathbf{5 0}$ & $\mathbf{2 5}$ & $\mathbf{1 2 . 5}$ & $\mathbf{6 . 2 5}$ & $\mathbf{3 . 1 3}$ & $\mathbf{1 . 5 6}$ & $\mathbf{0 . 7 8}$ & $\mathbf{0 . 3 9}$ & $\mathbf{C}(-)$ & $\mathbf{C}(+)$ \\
\hline \multirow{2}{*}{ S. aureus } & + & + & + & + & + & + & + & + & - & + \\
& + & + & + & + & + & + & + & + & - & + \\
\multirow{2}{*}{ P. aeruginosa } & + & + & + & + & + & + & + & + & - & + \\
& + & + & + & + & + & + & + & + & - & + \\
& + & + & + & + & + & + & + & + & - & + \\
\hline
\end{tabular}

Note: + : Bacterial colonies were present, - : Bacterial colonies were absent, $(+)$ : MH broth with tested bacteria suspension, (-) : 100\% J. multifida leaf infusion with MH broth 
have been produced surrounding the infusion holes with $100 \%$ and $75 \%$ infusion concentrations, however, bacterial growth still exists in the hole after examination with Gram staining. It is possible that the antibacterial contents in the infusion are not enough to kill the bacteria, as such only the bacteriostatic effect is observed.

The bacteriostatic effect is not observed in the MIC and MBC test. It is shown by the presence of bacterial growth in all of the tubes except in the negative control tube. This could be due to the concentration of the infusion. Even though the infusion with the highest concentration $(100 \%)$ has been used, the concentration becomes only 50\% after the mixing with Mueller Hinton broth. On the other hand, $50 \%$ infusion is failed to produce any inhibitory zones surrounding the holes in the antibacterial effect test.

Several studies have been done to examine the antibacterial effect of the different parts of $J$. multifida such as the leaves, barks, and sap. J. multifida leaf extract can inhibit the growth of M. tuberculosis at the concentration of $128 \mu \mathrm{g} / \mathrm{mL}^{1}{ }^{1}$ Interestingly, the bark extract of $J$. multifida has an inhibitory effect against several types of fungi and bacteria and has the potential to be an antimalarial drug. ${ }^{7}$ The sap of J. multifida can inhibit the growth of various bacteria. ${ }^{8}$ In other studies, the cream made of J. multifida sap can help the healing process of $S$. aureus infection on the external wounds on rats. ${ }^{4}$

There is a difference between this study and the previous studies in the form of the sample used. This study has used an infusion with water as its solvent, while other studies have made extracts with organic solvents such as ethanol. The advantages of using the infusion method are cheaper, faster, and simpler in terms of procedures and tools needed; meanwhile, extraction process requires prior knowledge about the contents of the plant and their respective suitable solvent. Suitable solvents are used to separate the active substances from the plant and dissolve them. After that, the separation of the active substances from the solvent is relatively easier to do to achieve a pure extract. This shows that extract production is more complicated and expensive than the infusion method and hence more difficult to be adopted by the common people. However, the infusion method also has some limitations, one of them being that the amount of the active substance extracted from the plants is less if compared to extract. Several studies have shown that the active substances that have Ann antibacterial effect in J. multifida leaves are flavonoid, saponin, and tannin. . $^{1,9,10}$ Flavonoid and tannin could dissolve in water and hence they are extractable by infusion, ${ }^{11}$ however, the extracted amount is still much smaller than if ethanol $96 \%$ is used. The use of ethanol $96 \%$ as the solvent can extract flavonoids and tannin twenty-five times more than when water is used. ${ }^{11}$

This study has some limitations. There are difficulties in producing infusion concentration higher than $100 \%$ because not all the leaves can be submerged in the water. The study could not use dried leaves because the storage was prone to contamination. Further studies to compare the antibacterial effect between J. multifida leaf infusion and its extract are interested to be explored.

To conclude, J. multifida leaf infusion has an antibacterial effect, which is bacteriostatic against $S$. aureus and $P$. aeruginosa.

\section{References}

1. Mina EC, Ibarra MR, Franzblau SG, Aguinaldo AM. Chemical and antitubercular screening on the leaves of Jatropha multifida Linn. Pure Appl Bio. 2014;2(1):32-6.

2. Falodun A, Igbe I, Erharuyi OY, Agbanyim OJ. Chemical characterization, antiinflammatory and analgesic properties of Jatropha multifida root bark. J Appl Sci Environ Manag. 2013;17(3):357-62.

3. Agoes Goeswin. Teknologi bahan alam. Bandung: Penerbit ITB; 2007. p.10-24.

4. Muntiaha MC, Yamlean PVY, Lolo WA. Uji efektivitas sediaan krim getah jarak cina (Jatropha multifida L.) untuk pengobatan luka sayat yang terinfeksi bakteri Staphylococcus aureus pada kelinci (Orytolagus cuniculus). PHARMACON. 2014;3(3):294-302.

5. Dwiprahasto I. Kebijakan untuk meminimalkan risiko terjadinya resistensi bakteri di unit perawatan intensif rumah sakit. JMPK. 2005;8(4):177-81.

6. Mahon CR, Lehman DC, Manuselis G. Textbook of diagnostic microbiology. 4th ed. USA: Saunders Elsevier; 2011. p.280-1.

7. Falodun A, Imieje V, Erharuyi O, Joy A, Langer $\mathrm{P}$, Jacob $\mathrm{M}$, et al. Isolation of antileishmanial, antimalarial and antimicrobial metabolites from Jatropha multifida. Asian Pac J Trop Biomed. 2014;4(5):374-8.

8. Aransiola MN, Ehikhase C, Mmegwa JC, Wahab IO. Antibacterial and antifungal 
activities of Jatropha multifida (ogege) sap against some pathogens. IOSR J Pharm Biol Sci. 2014;9(4):53-7.

9. Nuria MC, Faizatun A, Sumantri. Uji aktivitas antibakteri ekstrak etanol daun jarak pagar (Jatropha curcas L) terhadap bakteri Staphylococcus aureus ATCC 25923, Escheria coli ATCC 25922, dan Salmonella typhi ATCC 1408. MEDIAGRO. 2009;5(2):26-37.
10. Fahriya PS, Shofi MS. Ekstraksi zat aktif antimikroba dari tanaman yodium (Jatropha multifida L) sebagai bahan baku alternatif antibiotik alami. JTKI. 2011:1-7.

11. Agustiningsih, Wildan A, Mindaningsih. Optimasi cairan penyari pada pembuatan ekstrak daun pandan wangi (Pandanus amaryllifous R) secara maserasi terhadap kadar fenolik dan flavonoid total. Momentum. 2010;6(2):36-41. 